\title{
Learning and Teaching Ethics through Stories: A Few Examples from the Buddhist Tradition
}

\author{
Mehrdad Massoudi \\ Department of Biomedical Engineering, Carnegie Mellon University, Pittsburgh, USA. \\ Email: massoudi@netl.doe.gov
}

Received December $11^{\text {th }}, 2009$; revised February $18^{\text {th }}, 2010$; accepted April $2^{\text {nd }}, 2010$.

\begin{abstract}
The art of storytelling, similar to poetry, takes us to a different realm, yet always bringing us back to where we are. In many traditional societies, ethical concerns were taught through stories. A few stories from the Buddhist tradition have been selected to convey some basic teachings of the Buddha on ethical issues. This does not mean that these few stories capture the whole of Buddhist ethics. Furthermore, it is understood that similar stories can be found in other traditions, and therefore the same technique can be used in other religions as well. The universalities of these stories provide a means to teach ethics in a multi-cultural context.
\end{abstract}

Keywords: Ethics, Buddhism, Story Telling, Teaching

\section{Introduction}

"You cannot stay on the summit forever. You have to come down again, so why bother in the first place? Just this: What is above knows what is below, but what is below does not know what is above. One climbs and one sees; one descends and one sees no longer, but one has seen. There is an art of conducting oneself in the lower region by the memory of what one saw higher up. When one no longer sees, one can at least know."

Rene Daumel. Mount Analogue [1].

Living a spiritual life is very much similar to a journey taken by a traveler, especially that of a mountain climber. A journey starts from one point and ends at another; in a spiritual journey one goes from the "lower" self to the "higher" self, although there is only the Self. To ascend the mountain and reach the peak is one of the main objectives of living a spiritual life. There is no highway to enlightenment. The journey takes time; it requires tremendous sacrifices and hardship; sometimes a guide is necessary; it demands discipline, faith, and dedication. To live ethically is the "art of conducting oneself in the lower region." Occasional stopping and enjoying of the scenery is possible; but the goal is clear: To reach the mountaintop, to taste and experience the Truth. The teachers are the guides and the maps are the scriptures and the wisdom teachings; the task is to study the map and begin the climb. The teachers only point the way [2]. In his book, Dimensions of the Sacred, the scholar of world religions, Ninian Smart [3] lists seven important dimensions of religions as: 1) the ritual or the practical dimension; 2) the doctrinal or philosophical; 3) the mythic or narrative; 4) the experiential or emotional; 5) the ethical or legal; 6) the organizational or social; and 7) the material or artistic. In this essay the focus will be on the mythic or the narrative aspect and an attempt is made to show that stories have been used in most spiritual traditions to teach not only about myths but also about ethics.

There are many ways to characterize different religions; any given religion has different elements. Two points need to be emphasized. First: any religion provides (or should provide) a guideline, a map, for what one needs to do, what one needs to avoid, etc. Second: any religion provides (or should provide) guidelines for how one needs to react to external and internal variations. In other words, the test of suitability of a religion for an individual, in addition to the first point, where certain social guidelines are updated, is the second point, namely, how well the individual is capable of using this religion to react, to respond, and to interact with the external (and internal) circumstances. Religion in its wholeness connects the individual to the Source-that which one has been separated from, whether it is called God, the Truth, the Unnamable... According to many scholars, religion is what makes the person whole. Lama Govinda [4] says:

"As long as a religion (re-ligio, from re-ligare, to join again) is able to link its followers to that universal 
depth-zone of their consciousness, the nontransient, allembracing "divine ground of all being" that is not limited by time and space, it has fulfilled its function. For a religion must be capable of giving some meaning to existence. It must also point the way beyond the data of the senses and individual limitation toward a higher reality which can be attained by personal effort. Such a religion has value."

Religious ethics, unlike secular or humanistic ethics, is part of a bigger system; it is part of the religion which it originates from. Granting that certain aspects of all religions are historical, i.e., time and culture-bound, each religion contains a general code of ethics [5]. Though philosophers have different ways of classifying various types of ethics, such as deontologist, consequentialist ethics, or virtue ethics [6-13]. In this brief essay the position is taken that associated with each religion, there is a body of teaching which can be called the ethics of that religion; it is not to be extracted or separated from that religion. To the question "What is ethics?" Singer [12] gives a general and comprehensive answer that can also be used here:

"The word itself is sometimes used to refer to the set of rules, principles, or ways of thinking that guide, or claim authority to guide, the actions of a particular group; and sometimes it stands for the systematic study of reasoning about how we ought to act... But "ethics" and "morality" have their roots in a word for "customs", the former being a derivative of the Greek term from which we get "ethos", and the latter from the Latin root that gives us "mores", a word still used sometimes to describe the customs of a people."

There are those who say that one can be spiritual without being ethical, and there are those who say that unless one is able to lead an ethical life, no genuine spirituality is possible. Buddhism, similar to other religions has to respond to the issues of "conveniency", "efficiency", and "expediency" in the contemporary world. Buddhism, similar to other religions, has certain aspects of its teaching that can be categorized or named as "Buddhist Ethics," though perhaps it is more appropriate to talk of a Buddhist living a virtuous (ethical) life. Buddhist ethics can be called the "Ethics of Intention", the "Ethics of Consequences," the "Raft Ethics," a "Non-violent Ethics," the "Ethics of Interconnectedness," or.... Among certain groups the "Raft Ethics" is very popular. In this approach, the simile given by the Buddha (in the collection of discourses named the Majjhima Nikaya), where he uses the analogy that SILA (virtues, ethics) is similar to a raft for crossing the river, where the other shore is Nirvana. Accordingly, the person who has reached the other shore, i.e., an enlightened being, will not carry the raft on his or her back. Of course it goes without saying that the Buddha was referring to those who were already enlightened and had reached the other shore; for one who is still crossing the river of life, getting rid of the raft will only result in one's drowning.

Spirituality plays different roles at different times. Sometimes, one needs to comfort oneself and others about an unwanted situation. Sometimes one needs to be quiet and hope or pray. Sometimes one needs to address and challenge the injustices. While religion may conform to the laws of a society, spirituality can question those laws and the institutions enforcing those laws. In most spiritual traditions, frequent periods of retreat from the worldly activities are recommended, and in fact have become necessary. The two ultimate questions, namely 1) who we are, and 2) what we ought to do, are existential questions which one needs to struggle with and delve into, and while one is busy doing the same things and repeating the same activities, it would be very difficult to think of these two questions with any sense of continuity and depth.

In this essay, a few stories from the Buddhist tradition are selected to convey a sense of Buddhist ethics. This is not to say that these few stories capture the whole of Buddhist ethics; for comprehensive analysis of this issue see [14-17]. Furthermore, it is assumed that similar stories can be found in most other traditions, and therefore the same technique, i.e., using stories to teach ethics, can be used in other religions as well. The universalities of these stories provide a means to teach ethics in a multicultural context. In the next section, a brief overview of the teachings of the Buddha is provided, followed by a few stories pointing to certain aspects of the Buddhist ethics. The final section attempts to relate ethics to self-realization.

\section{The Basic Teachings of the Buddha}

If one looks at Buddhism as a school of philosophy rather than a way of living, then it is possible to look at its various elements such as epistemology, ontology, metaphysics, ethics, etc. [18-28]. To translate some of these into everyday discourse entails studying questions such as How do we know?, What do we know?, What should we do? etc. In this essay the concern is with the last of these questions.

The Noble Eightfold Path of Buddhism, which leads to the extinction of DUKKHA (the unsatisfactory nature of existence), consists of the following steps:

1) Right Understanding

2) Right Thought

3) Right Speech

4) Right Action

5) Right Livelihood

6) Right Effort

7) Right Mindfulness

8) Right Concentration

Perhaps a better way of representing these steps, avoiding a possible misunderstanding implying a hierar- 
chical or sequential structure, is to represent them in a circular manner. These eight steps are often represented or organized into three groups. In the first group, SILA (ethics, virtues) the three elements of Right Speech, Right Action, and Right Livelihood are put together. In the second group, SAMADHI (concentration, meditation), the three elements of Right Effort, Right Mindfulness, and Right Concentration are contained. In the third group, PRAJNA, the two elements of Right Understanding and Right Thought are grouped together. With a circular representation, one can see that each group affects the other two groups and is also affected by them.

The concern in this essay is with SILA (Right Speech, Right Action, and Right Livelihood). The word "Right" needs to be explained. While, the Pali word SAMMA is translated into English as "Right," it should be recognized that it is not the opposite of "Wrong," or "Bad." Lama Govinda [29] explains: "Samma (Skt. Samyak) means what is perfect or entire, that is, neither split nor one-sided; something, in fact, that is fully adequate to every level of consciousness." A Zen teacher, Albert Low [23] says: "The word 'right' does not mean right according to some perfect model or set of rules. Rather, it means without distortion brought about by the craving to be separate. Right mindfulness and right concentration, for example, establish a steady and clear mind, which is the foundation for an ethical and spiritual life." The traditional teachings of the Buddhist ethics are given in various SUTRAS (discourses) and books. For example, with regard to Right Speech, the Buddha said: [30]:

“1) Herein someone avoids lying and abstains from it. He speaks the truth, is devoted to the truth, reliable, worthy of confidence, not a deceiver of men. Being at a meeting, or amongst people, or in the midst of his relatives, or in a society, or in the king's court, and called upon and asked as witness to tell what he knows, he answers, if he knows nothing: "I know nothing", and if he knows, he answers: "I know"; if he has seen nothing, he answers: "I have seen nothing", and if he has seen, he answers: "I have seen." Thus he never knowingly speaks a lie, either for the sake of his own advantage, or for the sake of another person's advantage, or for the sake of any advantage.

2) He avoids tale-bearing, and abstains from it. What he has heard here, he does not repeat there, so as to cause dissention there; and what he has heard there, he does not repeat here, so as to cause dissention here. Thus he unites those that are divided; and those that are united, he encourages. Concord gladdens him, he delights and rejoices in concord; and it is concord that he spreads by his words.

3) He avoids harsh language, and abstains from it. He speaks such words as are gentle, soothing to the ear, loving, such words as go to the heart, and are courteous, friendly, and agreeable to many.
4) He avoids vain talk, and abstains from it. He speaks at the right time, in accordance with facts, speaks what is useful, speaks of the law and the discipline; his speech is like a treasure, uttered at the right moment, accompanied by arguments, moderate and full of sense."

The Right Action is described in [30]

"1) Herein someone avoids the killing of living beings, and abstains from it. Without stick or sword, conscientious, full of sympathy, he is desirous of the welfare of all living beings.

2) He avoids stealing, and abstains from it; what another person possesses of goods and chattels in the village or in the wood, that he does not take away with thievish intent.

3) He avoids unlawful sexual intercourse, and abstains from it. He has no intercourse with such persons as are still under the protection of father, mother, brother, sister, or relatives, nor with married women, nor female convicts, nor lastly, with betrothed girls."

And Right Livelihood is elaborated upon in different books and SUTRAS, for example [31]: "When the noble disciple, avoiding a wrong way of living, gets his livelihood by a right way of living, this is called Right Livelihood." In the Majjhima Nikaya [32] discourse No. 117, it is said: "To practice deceit, treachery, soothsaying, trickery, usury: this is wrong livelihood." And in the Anguttara Nikaya [30], it is said: "Five trades should be avoided by a disciple: trading in arms, in living beings, in flesh, in intoxicating drinks, and in poison." Included are the professions of a soldier, a fisherman, a hunter, etc.

What has been presented here in this section is really a very brief overview of the Buddha's teaching on ethics. More details can be found in $[14,15,17]$. In the next section, a few stories are taken mostly from the Zen Buddhist tradition to convey some of the essential ethical issues as presented in the Buddhist tradition.

\section{The Stories}

Stories have been used in many cultures throughout the ages not only to tell the story of a people, but also to point out to subtleties of life, to the intricacies of everyday dealings, often too dangerous or too sensitive to be mentioned in personal prose writings. Stories sometimes bring tears and sometimes laughter. Sometimes they present a sense of wonder and mystery. What may not be told in a logical and rational way, can be put in the form of a story. Stories are both means and ends. If they produce only tears and laughter, they are only a means for entertainment. On the other hand, if they point to a truth, then the stories themselves can become the ends. They are powerful tools for teaching, if used properly. Stories are at the heart of many spiritual traditions [33-35]. Stories need no introduction. They are in themselves the introduction, the content, and the conclusion. Stories have been used to teach, to point to a point, to emphasize 
something ... They have been passed down from generation to generation. Most of the stories dealing with spirituality and wisdom do not belong to a particular class or group of people. They have come to us from emanations of that Ultimate Wisdom. Just as paintings of Nature are at best reflections of the Nature in the mind of the artist, stories of Wisdom are reflections of that Ultimate Wisdom in the mind of the person, the teacher who is telling that story. While in many traditions, story-telling is an essential element, it is observed that the same idea appears in similar form in different traditions.

In the remainder of this section, five representative stories from the (Zen) Buddhist tradition are discussed. The first story is about a ROSHI [a Zen Master] called the "Bird's Nest Roshi who was doing zazen (sitting meditation)" [36]:

"He was a teacher who lived in the Tang period and did zazen in a tree. The governor of his province, Po Chu-i, heard about Bird's Nest Roshi and went to see him. This Po Chu-i was no ordinary politician. He was one of China's greatest poets, well known for his expression of Zen Buddhism. Po Chu-i found Bird's Nest Roshi sitting in his tree, doing zazen. He called to him, saying, 'Oh, Bird's Nest, you look very insecure to me up there.' Bird's Nest Roshi looked down at Po Chu-i and replied, 'Oh Governor, you look very insecure to me down there.' All things are under the law of change and political position is the most ephemeral of all. Po Chu-i knew very well what Bird's Nest Roshi was talking about. So he took a different tact. 'Tell me,' he said, 'What is it that all the Buddhas taught?' Bird's Nest Roshi replied by quoting from the Dhammapada:

Never do evil;

Always do good;

Keep your mind pure;

Thus all the Buddhas taught.

So Po Chu-i said, 'Always do good; never do evil; keep your mind pure-I knew that when I was three years old.' 'Yes,' said Bird's Nest Roshi, 'A three-year-old child may know it, but even an eighty-year-old man cannot put it into practice.",

This story which takes a few verses from the DHAMMAPADA [31], one of the sacred scriptures in Buddhism, can be considered to represent the essence of the teachings of the Buddha. It can be seen that the first statement (Never do evil) deals with the negative (or the preventive) aspects of the teachings, where evil actions in the context of Buddhist teachings become the unwholesome actions which are those actions related to unwholesome (improper) speech, conduct and thoughts. The second statement (Always do good) addresses the positive (or the prescriptive) aspects of the teaching. And the third statement (To keep your mind pure) points to the (inner) practices such as meditation, which are necessary to keep a balance between observing the precepts and developing compassion and wisdom. This balancing act is brought out in the next story:

"Two Buddhist monks came to the bank of a river and found it flooded and difficult to cross. A woman was waiting on the banks and she begged them to help her across, as her children were alone and hungry. One monk refused, the other picked her up and crossed the stream, holding her on his back. When they had crossed and were on their way again, the first monk protested vehemently. He was horrified that a monk should touch a woman, let alone carry her on his back. The second monk turned to him and said, "You mean you still carry the woman in your mind? I left her behind on the riverbank long ago."

This story points to a general theme, namely the relationship between the Letter of the Law and the Spirit of the Law. Developing the wisdom to know when the Spirit supersedes the Law is a challenge to a spiritual traveler. As a Zen Master said: "Zen is above morality, but morality is not below Zen." That is, Zen transcends morality but does not exclude it. A person who transcends morality is one who knows himself, one who has realized his true self, i.e., one who is enlightened, the subject matter of the third story [26]:

"When a rebel army swept into a town in Korea, all the monks of the Zen temple fled except the abbot. The general came into the temple and was annoyed that the abbot did not receive him with respect. 'Don't you know,' he shouted, 'that you are looking at a man who can run you through without blinking?'

'And you,' replied the abbot strongly, 'are looking at man who can be run through without blinking.'

The general stared at him, then made a bow and retired."

Only one who has realized his or her true nature can stand up and allow to be run through without blinking an eye. Only one who has tasted the Truth is capable of standing for Truth, Justice, Peace, Equality... This does not mean that one should wait until one is enlightened before one does anything helpful. It is the inner attitude of questioning and being humble that is of importance here. An enlightened (awaked or realized) being, similar to any other person, would encounter challenges and difficulties and it is the way in which he or she responds to the problems which reflects the degree of realization. Buddha told a parable [37]:

"A man was traveling across a field when he encountered a tiger. He began to run, and the tiger chased after him. Coming to a precipice, he slipped and was able to catch hold of the root of a wild strawberry bush, hanging in the air. The tiger sniffed at him from above. Trembling, the man looked down only to find that another tiger was waiting to eat him. He thought the bush could sustain him for a while, until he saw two mice gnawing away the vine. A tiger above, a tiger below. The man saw a ripe 
strawberry near him. Grabbing the vine with one hand, he plucked the strawberry with the other, and ate it. How sweet and delicious."

Buddhism stresses living in the present, here-and-now, and thus faces the ethics of the inevitably. This can be thought of as the receptive and accepting aspect of the Buddha's teaching: In certain situations in life, in the middle of here-and-now, there is not much one can do, except being mindfully present. To live fully, to suffer fully, and to die fully. One's life is an expression of who one is and what one stands for. When one is fully awake and present, one emits rays of clarity. The concepts of ignorance (darkness) and inner light are mentioned in the following story.

"In early times in Japan, bamboo-and-paper lanterns were used with candles inside. A blind man, visiting a friend one night, was offered a lantern to carry home with him. 'I do not need a lantern,' he said. 'Darkness or light is all the same to me.'

'I know you do not need a lantern to find your way,' his friend replied, 'but if you don't have one, someone else may run into you. So you must take it.'

The blind man started off with the lantern and before he had walked very far someone ran squarely into him. 'Look out where you are going!' he exclaimed to the stranger. 'Can't you see this lantern?'

'Your candle has burned out, brother,' replied the stranger."

This story [38] represents what could be called the "Lantern Ethics." The principles that one holds dear and the virtues that one aspires to have, give fuel to this lantern of enlightenment. This intense desire for understanding and realization is the candle that never burns out. For the candle to sustain the blows and the outside wind, a transparent protective cover is necessary. That shield is the ethics - the principles that one believes and holds unto. It can be seen that in the Buddhist tradition, based on these few stories, there is a relationship between ethics and awakening: how much one can live a wholeheartedly ethical life depends on how much one has become enlightened.

\section{The Importance of Ethics in (Self) Realization and Concluding Remarks}

In Buddhism, the two questions of "Who are we?" and "What must we do?" are connected through the element of Right Livelihood. In order to find out who we are, we need to have a profession which is "right," and in order to know what a "right" livelihood is for us, we have to know who we are. There is no universally accepted or prescribed catalogue listing all possible right livelihoods. The teachings of Buddha only provide the basic foundation where one can build upon. It is for each individual to constantly search and question one's livelihood.

Unless and until one has had the experience of the
Unity of Existence (Oneness, Nirvana), i.e., the feeling that "I" and "everything and everyone else" are transcendentally the same and connected, the path of enquiry will be full of perils and trials. As Socrates said [39, The Republic]: "We are discussing no small matter, but how we ought to live." On a spiritual path, oftentimes it is not possible to know with absolute certainty what is a right or a wrong action. This does not, however, mean that everything is relative. Every action will have many consequences; while taking the action might be relative, the consequences are real. As with most spiritual dilemmas there are no easy choices ${ }^{1}$. It is one thing to talk about or analyze various professions and categorize them accordingly as being "right," or "wrong," and it is another to judge people as "right" or "wrong" for having those professions. It is possible that a "good" father would be in a "bad" profession. The same act, depending on the circumstances and one's perception, could lead to different responses. What one may consider a right livelihood (for oneself), under different circumstances or at a different time and a different place may be considered a wrong livelihood. Whilst in the middle of a war, or living in a corrupt environment, one can still think and hope for peace, purity and good. Although it is difficult to generalize as to what constitutes "right livelihood," there are available guidelines. For example, Coomaraswamy [40] says: "...if there are any occupations that are not consistent with human dignity, or manufactures however profitable that are not of real goods, such occupations and manufactures must be abandoned by any society that has in view the dignity of all its members. It is only when measured in terms of dignity and not merely in terms of comfort that a 'standard of living' can properly be called 'high'". One can say that even though virtues may not be taught, virtues can be learned [41]. That is, as Aristotle said: "One becomes virtuous by performing virtues."

In Buddhism, the conception of the ideal, the ethical ideal, is one of happiness, perfection, realization, and liberation [42], where happiness is the desire for all beings to be happy. But if one does not know what gives rise to true happiness for oneself, how can one wish that happiness for all beings? Buddha in Sutta 21 of Digha Nikaya [43] discusses this:

"... I declare that there are two kinds of happiness: the kind to be pursued, and the kind to be avoided. The same

${ }^{1}$ For a father whose children are starving, is it "right" to steal money or food? For a husband who wants to provide his wife with the necessary medicine, or a shelter, is it "right" to participate in destructive activities of any type? For a mother whose baby is dying, is it "right" to sell herself so that she can buy food for her baby? And.... Of course, we are not talking about greed, possessiveness, or aggressiveness here; we are talking about very caring people whose responsibility or love cause them to do something which someone else would judge as "wrong" livelihood. As Singer [11] says: "Ethics does not demand that we eliminate personal relationships and partial affections, but it does demand that when we act we assess the moral claims of those affected by our actions independently of our feelings for them." 
applies to unhappiness and equanimity. Why have I declared this in regard to happiness? This is how I understood happiness: When I observed that in the pursuit of such happiness unwholesome factors increased and wholesome factors decreased, then that happiness was to be avoided. And when I observed that in the pursuit of such happiness unwholesome factors decreased and wholesome ones increased, then that happiness was to be sought after. Now, of such happiness as is accompanied by thinking and pondering, and of that which is not so accompanied, the latter is more excellent. The same applies to unhappiness, and to equanimity."

Therefore a skillful approach is to see what these unwholesome factors are; these are discussed in Sutta 9, of Majjhima Nikaya [32]:

"And what, friends, is the unwholesome, what is the root of the unwholesome, what is the wholesome, what is the root of the wholesome? Killing living beings is unwholesome; taking what is not given is unwholesome; misconduct in sensual pleasures is unwholesome; false speech is unwholesome; malicious speech is unwholesome; harsh speech is unwholesome; gossip is unwholesome; covetousness is unwholesome; ill will is unwholesome; wrong view is unwholesome. This is called the unwholesome. And what is the root of the unwholesome? Greed is a root of the unwholesome; hate is a root of the unwholesome; delusion is a root of the unwholesome. This is called the root of the unwholesome."

That is, real happiness is a happiness founded on an ethical life. One of the most distinctive aspects of Buddhist ethics, and in fact Buddhist philosophy, is that of "Interconnectedness" or the "Principle of Dependent Origination". This Principle implies that everything and everybeing is connected and related to every other thing and every other being; all beings inter-are or are interconnected throughout time and space, in a spiritual sense. The Buddha said [44]:

"When this is, that comes to be.

With the arising of this, that arises.

When this is not, that does not come to be.

With the cessation of this, that ceases."

It is this sense of connectedness which makes Buddhist approach to social issues such as peace, justice, equality different from the current trends of violent protests, name-calling, and finger-pointing [45]. One can infer from this Principle that for example, unless one has truly become a peaceful person, one cannot seek peace outside.

May we have the courage and the strength to become like the abbot who could be run through without blinking an eye.

May we acquire the mindfulness to remember and live the simple truths that even a three-year-old knows.

May we develop the compassion necessary to help others and relieve their suffering as the monk who car- ried the woman to the other side of the river.

May our love reach those whom we have classified as our enemies, starting with one's self.

And may we learn that inner wisdom which shines like the lantern that never goes out.

There are those who say that one can be spiritual without being religious. There are those who say spirituality begins where religion ends. There are those who say that only religious people, i.e., those who believe in a religion, can be spiritual. An analogy might be helpful. If one looks at a nut (walnut, almond, peanut, etc.), there is the shell, the seed, and the oil. The oil can be considered the essence: that which can be squeezed from the seed. But first the shell must be broken. The shell is the relative and the particular (dogmatic) aspects of the religion. The seed (spirituality) is that which will produce the oil: the truth within that religion (shell). If one just wants the oil without going through the process of breaking the shell, squeezing the seed, then this process of spiritual maturation is missed. There are no short cuts to the essence [46].

\section{REFERENCES}

[1] R. Daumel, "Mount Analogue," Shambhala Publications, Boston, 1986.

[2] M. Massoudi, "On the Qualities of a Teacher and a Student: An Eastern Perspective Based on Buddhism, Vedanta, and Sufism," Intercultural Education, Vol. 13, No. 2, 2002, pp. 137-155.

[3] N. Smart, "Dimensions of the Sacred: An Anatomy of the World's Beliefs," University of California Press, Berkeley, 1996.

[4] Govinda, Lama Anagarika, "Buddhist Reflections," Samuel Weiser, Inc., York Beach, 1991, p. 34.

[5] H. Kung, "Global Responsibility: In Search of a New World Ethic," The Continuum Publishing Company, New York, 2001.

[6] L. Kavelin-Popov, "The Family Virtues Guide," Penguin Books of Canada, Ltd., 1997.

[7] M. Midgley, "Why Can’t We Make Moral Judgements," St. Martin's Press, Inc., New York, 1993.

[8] J. Rachels, "The Elements of Moral Philosophy," 2nd Edition, McGraw Hill, New York, 1993.

[9] T. Regan, “All That Dwell Therein," University of California Press, Berkeley, 1982.

[10] T. Regan, "The Thee Generation," Temple University Press, Philadelphia, 1991.

[11] P. Singer, "Practical Ethics," Cambridge University Press, Cambridge, 1979, p. 67.

[12] P. Singer, (Ed.) "Ethics," Oxford University Press, Oxford, 1994, p. 4.

[13] P. Singer, "How are We to Live?" Prometheus Books, Amherst, New York, 1995. 
[14] P. Harvey, “An Introduction to Buddhist Ethics," Cambridge University Press, Cambridge, 2000.

[15] D. Keown, "The Nature of Buddhist Ethics," Palgrave, Hampshire, 2001.

[16] W. Rahula, "What the Buddha Taught," Grove Press, Inc., New York, 1974.

[17] H. Saddhatissa, "Buddhist Ethics," Wisdom Publications, London, 1987.

[18] A. Masao, "Zen and Western Thought," In: W. R. LaFleur, Ed., Traditions of Meditation in Chinese Buddhism, University of Hawaii Press, Honolulu, HI, 1985.

[19] Dalai Lama, "The Wisdom Teachings of the Dalai Lama,” In: M. E. Bunson, Ed., Penguin Books, Inc., New York, 1997.

[20] Dogen Zenji, "Moon in a Dewdrop," In: K. Tanahashi, Ed., North Point Press, San Francisco, 1985.

[21] P. Kapleau, "The Three Pillars of Zen," Anchor Books, Doubleday, New York, 1980.

[22] P. Kapleau, "Zen, Dawn in the West," Anchor Books, Doubleday, New York, 1979.

[23] A. Low, "An Invitation to Practice Zen," Charles E. Tuttle Company, Rutland, 1989.

[24] Ven Nyanatiloka, "The Word of the Buddha," 14th Edition, Buddhist Publication Society, Kandy, Ceylon, 1967.

[25] Ven Sangharakshita, "A Survey of Buddhism," 7th Edition, Windhorse Publications, Scotland, 1993.

[26] J. Snelling, "Elements of Buddhism," Elements Books, Dorset, 1990, p. 51.

[27] F. Story, "Dimensions of Buddhist Thought," Buddhist Publication Society, Kandy, Sri Lanka, 1976.

[28] D. T. Suzuki, "An Introduction to Zen Buddhism," Grove Press, Inc., New York, 1964.

[29] Govinda, Lama Anagarika, "A Living Buddhism for the West," Shambhala Publications, Inc., Boston, 1989, p. 31.

[30] F. L. Woodward, (Translator) "Anguttara-Nikaya (The Book of Gradual Sayings)," Vol. 1, Pali Text Society, Oxford, 1989.

[31] F. M. Muller, (Translator) "Dhammapada (The Sacred Books of the East)," Vol. 10, Motilal Banarsidass, Delhi,
1988.

[32] B. Nanamoli and B. Bodhi, (Translators) "Majjhima Nikaya (The Middle Length Discourses of the Buddha)," Wisdom Publications, Boston, 1995, p. 132.

[33] M. Buber, "Tales of the Hasidim," Schocken Books Inc., New York, 1947.

[34] M. Bayat and M. A. Jamnia, "Tales from the Land of the Sufis," Shambhala Publications, Inc., Boston, 1994.

[35] J. Kornfield and C. Feldman, "Soul Food: Stories to Nourish the Spirit and the Heart," Harper San Francisco, New York, 1991.

[36] R. Aitken, "Taking the Path of Zen," North Point Press, San Francisco, 1982, p. 87.

[37] R. Sohl and A. Carr, (Ed.) "The Gospel According to Zen," A Mentor Book, New York, 1970, p. 57.

[38] P. Reps, “Zen Flesh, Zen Bones," Anchor Books, New York, 1957, p. 79.

[39] Plato, "The Collected Dialogues of Plato," In: E. Hamilton and H. Cairns, Ed., Princeton University Press, Princeton, 1961.

[40] A. K. Coomaraswamy, "The Bugbear of Literacy," Perennial Books Ltd., Bedfont, Middlesex, England, 1979, p. 20.

[41] B. Darling-Smith, (Ed.) “Can Virtue be Taught?” University of Notre Dame Press, Indiana, 1993.

[42] K. N. Jayatilleke, "The Message of the Buddha," In: N. Smart Ed., and introduced, Buddhist Publication Society, Kandy, Sri Lanka, 2000.

[43] M. Walshe, (Translator) "Thus have I heard. The Long Discourses of the Buddha; Digha Nikaya," Wisdom Publications, Boston, 1987, p. 329.

[44] J. D. Ireland, (Translator) "The Udana: Inspired Utterances of the Buddha," Buddhist Publication Society, Kandy, Sri Lanka, 1990.

[45] S. Sivaraksa, "Seeds of Peace; a Buddhist Vision for Renewing Society," Parallax Press, Berkeley, 1992.

[46] H. Smith, "Forgotten Truth," Harper, San Francisco, 1992. 